\section{Substitution of Academically Trained by Other \\ Manpower}

Jan Tinbergen

Weltwirtschaftliches Archiv

Volume 111 / 1975 / Issue 3 / Article

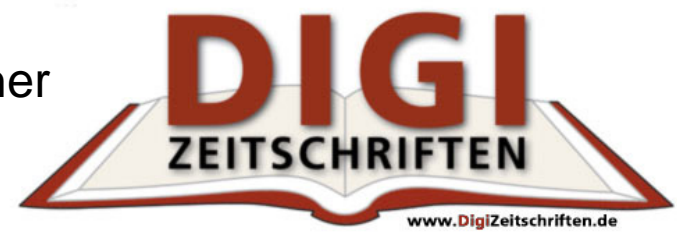

www.Digizeitschriften.de

\title{
Nutzungsbedingungen
}

DigiZeitschriften e.V. gewährt ein nicht exklusives, nicht übertragbares, persönliches und beschränktes Recht auf Nutzung dieses

Dokuments. Dieses Dokument ist ausschließlich für den persönlichen, nicht kommerziellen Gebrauch bestimmt. Das Copyright bleibt bei den Herausgebern oder sonstigen Rechteinhabern. Als Nutzer sind Sie sind nicht dazu berechtigt, eine Lizenz zu übertragen, zu transferieren oder an Dritte weiter zu geben.

Die Nutzung stellt keine Übertragung des Eigentumsrechts an diesem Dokument dar und gilt vorbehaltlich der folgenden Einschränkungen: Sie müssen auf sämtlichen Kopien dieses Dokuments alle Urheberrechtshinweise und sonstigen Hinweise auf gesetzlichen Schutz beibehalten; und Sie dürfen dieses Dokument nicht in irgend einer Weise abändern, noch dürfen Sie dieses Dokument für öffentliche oder kommerzielle Zwecke vervielfältigen, öffentlich ausstellen, aufführen, vertreiben oder anderweitig nutzen; es sei denn, es liegt Ihnen eine schriftliche Genehmigung von DigiZeitschriften e.V. und vom Herausgeber oder sonstigen Rechteinhaber vor.

Mit dem Gebrauch von DigiZeitschriften e.V. und der Verwendung dieses Dokuments erkennen Sie die Nutzungsbedingungen an.

\section{Terms of use}

DigiZeitschriften e.V. grants the non-exclusive, non-transferable, personal and restricted right of using this document. This document is intended for the personal, non-commercial use. The copyright belongs to the publisher or to other copyright holders. You do not have the right to transfer a licence or to give it to a third party.

Use does not represent a transfer of the copyright of this document, and the following restrictions apply:

You must abide by all notices of copyright or other legal protection for all copies taken from this document; and You may not change this document in any way, nor may you duplicate, exhibit, display, distribute or use this document for public or commercial reasons unless you have the written permission of DigiZeitschriften e.V. and the publisher or other copyright holders.

By using DigiZeitschriften e.V. and this document you agree to the conditions of use.

\section{Kontakt / Contact}

DigiZeitschriften e.V.

Papendiek 14

37073 Goettingen

Email: digizeitschriften@sub.uni-goettingen.de 


\title{
Substitution of Academically Trained by Other Manpower
}

\author{
By
}

\author{
Jan Tinbergen
}

I. In recent years a number of estimates have been made of the impact of an increased supply of academically trained - or other highly qualified - manpower on their relative incomes, that is the ratio of their (labour) income to earnings of other manpower. Clearly this impact will be higher, the lower the substitutability of this highly trained manpower by other manpower. This essay is an attempt to comment on the estimates so far come to the author's knowledge and to add some further evidence. Both comments and new estimates are based on a demandsupply theory of income formation. Demand is assumed to be exerted by the organizers of production in the widest sense and to be derived from the maximization of profits, with as a main constraint a production function. Supply of manpower is supposed to be decided upon by individuals of working age, derived in principle from the maximization of utility, with as constraints some personality traits. Individual studies may differ in the degree of explicitness in using production functions and utility functions. Their fully explicit use is more satisfactory from a methodological point of view, but implies more arbitrary choices of specification than an empiristic approach, where specifications mostly refer to variables introduced into a multiple regression analysis and mathematical shapes of demand or supply functions are experimented with. An important aspect of empirical estimation of demand elasticities, whether absolute or relative (as in the case of substitution elasticities), is the problem of identification. A simple relationship between employment and prices (incomes) can only yield a demand elasticity if we assume that the observed points are situated on a demand curve or surface, implying that shifts have occurred only on the supply side. Inversely a supply relation can only be derived from observations on employment and prices alone if we assume that only the demand function has shifted. A well-known method to estimate, from observations on employment
\end{abstract}


and prices, both a demand and a supply relation consists of adding other variables and hence use multiple regression analysis. The additional variables used in the demand equation are often called demand factors, those in the supply equation supply factors. Another method consists of introducing a lag in one of the two relations.

A simple example may illustrate this approach. All symbols will be taken to represent logarithms of the variables to be mentioned. Let $\mathrm{x}$ be employment, $\mathrm{p}$ price (income), s a supply factor and $\mathrm{d}$ a demand factor.

The supply equation is assumed to be:

$$
\mathrm{x}=\alpha_{1} \mathrm{~s}+\alpha_{2} \mathrm{P}
$$

and the demand equation:

$$
x=\beta_{1} d-\beta_{2} p
$$

To fix the ideas we may further assume that $\mathrm{s}$ represents the total number of academically trained manpower available and $d$ the number desired by the organizers of production. Other choices are perfectly possible, however. The one chosen here implies that not necessarily all academics available will actually be employed and that the organizers of production need not be able to attract all academics they desire from a technical point of view. Several authors who assumed $\mathrm{x}=\mathrm{s}$ have opted, therefore, for $\alpha_{1}=1$ and $\alpha_{2}=0$; we should be aware of this being not necessarily realistic.

It is well known that unbiased estimates of the coefficients can be obtained by testing statistically the reduced forms of (I) and (2), obtained by solving ( $\mathrm{I}$ ) and (2) for $\mathrm{p}$ and $\mathrm{x}$ respectively, yielding:

(i) the "price equation" $\quad \mathrm{p}=-\pi_{1} \mathrm{~s}+\pi_{2} \mathrm{~d}$

and

(ii) the "employment equation" $\quad \mathrm{x}=\xi_{1} \mathrm{~s}+\xi_{2} \mathrm{~d}$

where

$$
\pi_{1}=\frac{\alpha_{1}}{\alpha_{2}+\beta_{2}} \quad \pi_{2}=\frac{\beta_{1}}{\alpha_{2}+\beta_{2}}
$$

and

$$
\xi_{1}=\frac{\alpha_{1} \beta_{2}}{\alpha_{2}+\beta_{2}} \quad \xi_{2}=\frac{\alpha_{2} \beta_{1}}{\alpha_{2}+\beta_{2}}
$$

An application of this approach will be given in Section 5 . 
2. We will first comment on some work done by other authors. The main characteristics and findings have been summarized in Tables I and 2 , indicating, respertively, demand and supply elasticities of substitution of academically (or alternatively higher) trained labour by other (sometimes all other, sometimes some other) labour.

The OECD study ${ }^{1}$, like one of our own, assumes the Cobb-Douglas production function, where all $\sigma_{i k}=-\mathrm{I}\left(\sigma_{i k}\right.$ is the (partial) substitution elasticity between factors $i$ and $k$ as against all other factors). It should be noted that the $\mathrm{R}$ obtained is satisfactory.

Dougherty's analysis ${ }^{2}$ estimates all substitution elasticities between any pair of eight educational categories and arrives at very high values, negative in the more significant statistical results; and so do Bowles and Psacharopoulos and Hinchliffe ${ }^{3}$, who only introduce three or four educational categories. High negative values for the elasticities of substitution between academically trained and other manpower are also found by Dresch ${ }^{4}$ who uses time series data and, like the other authors mentioned, assumes a CES production function. They are supported, moreover, by the results Berndt and Christensen ${ }^{5}$ find with the aid of translog production functions and Freeman ${ }^{6}$ who does not specify a production function. Fallon and Layard ${ }^{7}$, in contrast, find - $0.6 \mathrm{I}$; and Mrs. Ullman Chiswick ${ }^{8}$, although choosing a value - 2.5, derives this from a regression of wages on employment with a correlation of about 0.8 . Had she taken the regression of employment on wages then her result might have been close to $-2.5 \mathrm{R}^{2}$ or about - I.5.

1 OECD, Occupational and Educational Structures of the Labour Force and Levels of Economic Development, Paris, I97r, p. 8r.

${ }^{2}$ C. R.S. Dougherty, "Estimates of Labor Aggregation Functions", The Journal of Political Economy, Vol. 8o, Chicago, Ill., I972, pp. Iror sqq.

${ }^{3}$ Samuel Bowles, Planning Educational Systems for Economic Growth, Harvard Economic Studies, Vol. I33, Cambridge, Mass., I969. - George Psacharopoulos and Keith Hinchliffe, "Further Evidence on the Elasticity of Substitution among Different Types of Educated Labor", The Journal of Political Economy, Vol. 8o, 1972, pp. 786sqq.

${ }^{4}$ Stephen P. Dresch, "Demography, Technology and Higher Education: Toward a Formal Model of Educational Adaptation", The Journal of Political Economy, forthcoming.

5 Ernst R. Berndt and Laurits R. Christensen, The Specification of Technology in American Manufacturing, Discussion Paper 73-r7, University of British Columbia, October I973. Idem, "Testing for the Existence of a Consistent Aggregate Index of Labor Inputs", The American Economic Review, Vol. 64, Menasha, Wisc., I974, pp. 39r sqq.

${ }^{6}$ R. B. Freeman, The Market for College-Trained Manpower, Cambridge, Mass., I97I.

7 P. R. Fallon and P. R. G. Layard, Capital-Skill Complementarity, Income Distribution and Output Accounting, Higher Education Research Unit, London School of Economics, I974.

${ }^{8}$ C. Ullman, The Growth of Professional Occupations in the American Labor Force:

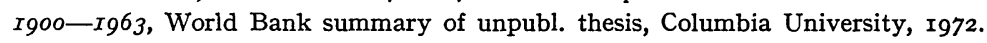


Table I - Summary of Research Done on the Demand Elasticity of Substitution between Academically Trained and Other Labour by Other Authors

\begin{tabular}{|c|c|c|c|c|c|}
\hline Author(s) & $\begin{array}{l}\text { Nature of } \\
\text { analysis }\end{array}$ & $\begin{array}{c}\text { Production } \\
\text { function }\end{array}$ & $\begin{array}{c}\text { Substitution } \\
\text { elasticity }\end{array}$ & $\begin{array}{l}\text { Other explana- } \\
\text { tory variables }\end{array}$ & $\mathrm{R}$ \\
\hline $\mathrm{OECD}$. . & $\begin{array}{l}\text { cross section } \\
22 \text { countries }\end{array}$ & $\begin{array}{c}\text { Cobb- } \\
\text { Douglas }\end{array}$ & $-\mathrm{I}$ & $\begin{array}{l}\text { capital, other } \\
\text { labour }\end{array}$ & 0.95 \\
\hline Dougherty & $\begin{array}{l}\text { cross section } \\
28 \text { US states }\end{array}$ & CES & $\begin{array}{c}-6.0 \text { to } \\
25.5\end{array}$ & $\begin{array}{l}\text { each of seven } \\
\text { other educa- } \\
\text { tional groups }\end{array}$ & n.s. ${ }^{b}$ \\
\hline Bowles & $\begin{array}{l}\text { cross section } \\
\text { I } 2 \text { countries }\end{array}$ & CES & $-4.8^{\mathrm{c}}$ & $\begin{array}{l}\text { perc. inc. } \\
\text { from agr. }\end{array}$ & 0.90 \\
\hline $\begin{array}{l}\text { Psacharopoulos } \\
\text { and Hinchliffe }\end{array}$ & $\begin{array}{l}\text { cross section } \\
\text { I } 8 \text { countries }\end{array}$ & CES & -2.2 & none $^{a}$ & n.s. $b$ \\
\hline Dresch . . & $\begin{array}{l}\text { time series } \\
\text { USA } 1956-68\end{array}$ & CES & -3.82 & none ${ }^{a}$ & 0.985 \\
\hline $\begin{array}{l}\text { Fallon and } \\
\text { Layard }\end{array}$ & $\begin{array}{r}\text { cross sections } \\
22 \text { countries }\end{array}$ & $\begin{array}{l}\text { CES } \\
\text { 2-stage }\end{array}$ & $\begin{array}{l}-0.6 \mathrm{I} \\
-3.54\end{array}$ & $\begin{array}{l}\text { phys. cap. }{ }^{\mathrm{d}} \\
\text { phys. cap. }\end{array}$ & $\begin{array}{l}\text { n.s. }{ }^{b} \\
\text { n.s. }\end{array}$ \\
\hline $\begin{array}{l}\text { Berndt and } \\
\text { Christensen }\end{array}$ & $\begin{array}{l}\text { time series } \\
\text { USA I929-68 }\end{array}$ & translog & $\begin{array}{l}-4.9 \text { to } \\
-6.1\end{array}$ & none $^{a}$ & 0.95 \\
\hline Freeman ${ }^{f}$. & time series & n.s. ${ }^{b}$ & -2.3 & & n.s. ${ }^{b}$ \\
\hline Ullman & \begin{tabular}{|l} 
time series \\
USA 1900-63
\end{tabular} & n.s. $b$ & $-\mathrm{r} .5^{\mathrm{c}}$ & $\begin{array}{l}\text { quality of } \\
\text { labour }\end{array}$ & 0.8 \\
\hline \multicolumn{6}{|c|}{$\begin{array}{l}\text { a Implying that identification is doubtful. - b Not specified. - c For regression } \\
\text { of employment on income ratios. - d Part of complete model; in production function } \\
\text { physical and human capital supposed to be complementary. - e Part of complete } \\
\text { model; qualified and "raw" labour assumed complementary (Bowles specification). - } \\
\text { f Derived from flow analysis by present author. }\end{array}$} \\
\hline
\end{tabular}

Whereas the first impression one gets from Table I must be in favour of a substitution elasticity well below - I (i.e. showing a higher absolute value), my thesis is that this impression is not warranted. The main reason for this conclusion is that the relationships measured are not clearly identifiable as demand relations. Berndt and Christensen explicitly admit that no attempt was made to identify the relation as such. Freeman restricts his demand and supply analysis to the flow of new entrants and the figure shown in Table I has been derived from his demand equation by dividing his elasticity, - Io, by the ratio of the total stock of academic manpower to the four-year flow he considers. Mrs. Ullman Chiswick does specify separate demand and supply functions, but does not add, at the demand side, an index of industrial structure of the various states and, 
Table 2 - Supply Elasticity of Substitution between Academically Trained and Other Labour

\begin{tabular}{|c|c|c|c|c|}
\hline Author(s) & Nature of analysis & $\begin{array}{l}\text { Substitution } \\
\text { elasticity }\end{array}$ & Remarks & $\mathrm{R}$ \\
\hline Dresch & supply of entrants & $\begin{array}{l}2.1 \\
0.08^{b}\end{array}$ & $\begin{array}{l}\text { single } \\
\text { regression }\end{array}$ & n.m. ${ }^{a}$ \\
\hline Freeman & supply of entrants & $\begin{array}{l}\mathrm{I} \\
0.06^{b}\end{array}$ & $\begin{array}{l}\text { multiple } \\
\text { regression }\end{array}$ & 0.97 \\
\hline Ullman . & supply of stock & $-\mathrm{r} .25^{\mathrm{c}}$ & & $0.7 \mathrm{I}^{\mathrm{d}}$ \\
\hline Tinbergen & Bowles material & $-\underset{8.5^{f}}{I} 2^{e}$ & $\begin{array}{l}\text { cross section } \\
\text { I } 2 \text { countries }\end{array}$ & $\begin{array}{c}0.70 \\
0.47^{\mathrm{d}} 0.85^{\mathrm{g}}\end{array}$ \\
\hline Tinbergen & Dougherty material & $\begin{array}{l}0.54^{e} \\
2.64^{f}\end{array}$ & $\begin{array}{l}\text { cross section } \\
28 \text { US states }\end{array}$ & $\begin{array}{c}0.8 \mathrm{I} \\
0.80^{\mathrm{d}} 0.85^{\mathrm{g}}\end{array}$ \\
\hline \multicolumn{5}{|c|}{$\begin{array}{l}\text { a Not mentioned. }-\mathrm{b} \text { supply elasticity for stock. }-\mathrm{c} \text { Her suggestion how to obtain } \\
\text { a positive sign has not, in her own publication, been elaborated. }-\mathrm{d} \text { Reduced-form } \\
\text { price equation. - e From least-squares estimation of supply function. }-\mathrm{f} \text { From } \\
\text { reduced-form price and quantity equations. }-\mathrm{g} \text { Reduced-form quantity (employment) } \\
\text { equation. }\end{array}$} \\
\hline
\end{tabular}

like many other authors, identifies quantity supplied (employed) with quantity of available academically trained manpower.

3. Since the credibility of the figures obtained for demand elasticity also should depend on the credibility of the supply elasticity figures, the latter have been shown in Table 2. Both Dresch and Freeman studied the supply of entrants only. If their elasticities are transformed into stock supply elasticities, the latter become very low. Mrs. Ullman Chiswick is the only author mentioned in this table who estimated a stock supply elasticity, but found a rather high negative figure ( - I.25). She adds a suggestion, however, how to arrive at lower negative or even positive values, by adding to her supply function a term in $h_{2} / h_{1}$, that is the relative quantities of human capital invested in the two types of labour considered. If the coefficient $a_{5}$ in front of this variable is varied from 0 to -1 , the supply elasticity proper changes from - I.25 (which would seem rather too high) to + o.I7. We will use these results in Section 5.

Using Bowles's and Dougherty's material, but adding one supply factor $^{1}$, I arrived at the figures added to Table 2 in the last four lines. The supply factor added to Bowles's material is labour with secondary education, the one added to Dougherty's material the median years of

${ }^{1}$ Jan Tinbergen, "Substitution of Graduate by Other Labour", Kyklos, Vol. 27, Basel, 1974, p. 217. 
schooling. For each case two estimates are made; the upper figure is the outcome of a least-squares estimate, the lower one results from a reducedform regression. At the one percent level the figure $-I$ is insignificantly different from zero and hence more or less in line with the results derived from Dresch's and Freeman's analyses. The three other figures are considerably higher and have the correct sign.

Although the picture obtained is not uniform, a low positive supply elasticity seems to be the central tendency of Table 2. Let us now return to the demand elasticity again.

Adding a demand factor (in Bowles's analysis: per mille of the active population in utilities, health services, transportation and communication; in Dougherty's: percentage of the active population employed in transportation, etc., finance, professional services and public administration) I estimated the demand elasticities of substitution between highly trained and other labour and found the results shown in Table 3.

Table 3 - Demand Substitution Elasticities Found by Adding a Demand Factor to Other Studies ${ }^{1}$

\begin{tabular}{|c|c|c|c|}
\hline \multirow{2}{*}{ Material from } & \multicolumn{2}{|c|}{ Least squares } & \multirow{2}{*}{ Reduced form } \\
\hline & Ist regression & 2nd regression & \\
\hline 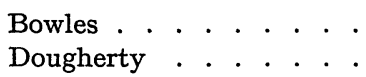 & $\begin{array}{l}-\mathrm{I} .2 \\
-0.4\end{array}$ & $\begin{array}{l}-\mathrm{I} .5 \\
-2.1\end{array}$ & $\begin{array}{l}-0.6 \\
-0.85\end{array}$ \\
\hline
\end{tabular}

These results suggest that the problem of the correct identification of the relationships tested is of vital importance to the estimation of demand substitutability of highly qualified labour.

4. Some light on the problem of incomes of academically trained manpower can also be thrown by the simple demand elasticity for this type of labour. If academically trained labour can be easily replaced by other types, its demand elasticity (with regard to its price or income) must be rather high; if not, it must be rather low. Hence it seems more useful to directly estimate $\varepsilon_{i i}=\frac{p_{i}}{x_{i}} \frac{\partial x_{i}}{\partial p_{i}}$. In Table 4 three such estimates are shown; the first two from earlier work by this author ${ }^{2}$.

For the Netherlands a cross-section analysis was made between provinces in order to explain the upper decile $\mathrm{x}^{\prime \prime}$ with the aid of $\mathrm{y}^{\prime \prime}$,

\footnotetext{
1 Tinbergen, op. cit.

${ }^{2}$ Idem, Income Distribution: Analysis and Policies, Amsterdam, 1975, Equations (3.5) and (3.6).

Weltwirtschaftliches Archiv Bd. CXI. 
a demand index, $z^{\prime \prime \prime}$, the percentage of active population with secondary and third-level education and $u^{\prime \prime}$, the percentage of that population with third-level education. In standardized variables the multiple regression equation found is:

$$
\mathrm{x}^{\prime \prime}=2.95 \mathrm{y}^{\prime \prime}-0.08 \mathrm{z}^{\prime \prime \prime}-\mathrm{I} .75 \mathrm{u}^{\prime \prime} \quad(\mathrm{R}=0.96)
$$

This implies that a $\mathrm{x} \%$ increase in $\mathrm{u}^{\prime \prime}$ causes a reduction in $\mathrm{x}^{\prime \prime}$ by I.75 per cent; the corresponding demand elasticity being $\frac{-I}{I .75}=-0.57$.

For the United States a relation was used, in a cross-section analysis for states:

$$
\mathrm{X}^{\prime}=0.047 \mathrm{Y}^{\prime}-0.194 \mathrm{Z}+0.160 \mathrm{U}^{\prime} \quad(\mathrm{R}=0.77)
$$

where the meaning of the symbols is:

$\mathrm{X}^{\prime}$ upper decile of income distribution, divided by median income,

$\mathrm{Y}^{\prime}$ a demand index for labour with third-level education,

$\mathrm{Z}$ average years of schooling of state considered,

$\mathrm{U}^{\prime}$ standard deviation of years of schooling.

If we split up the population of the United States into those with third-level education (assumed to have a schooling figure of $I 6$ years) and the remainder with schooling $\mathrm{s}$, then, since the former constitute I9 per cent, we find $s=8.8$ years. If now we assume that the number of

Table 4 - Additional Estimations of Demand Elasticity for Academics

\begin{tabular}{|c|c|c|c|c|}
\hline $\begin{array}{l}\text { Country } \\
\text { Year }\end{array}$ & $\begin{array}{l}\text { Nature of } \\
\text { analysis }\end{array}$ & $\begin{array}{l}\text { Demand factor } \\
\text { used }\end{array}$ & $\begin{array}{l}\text { Demand } \\
\text { elasticity }\end{array}$ & $\mathrm{R}$ \\
\hline $\begin{array}{l}\text { Netherlands } \\
\text { I960 }\end{array}$ & $\begin{array}{l}\text { cross section } \\
\text { II provinces }\end{array}$ & $\begin{array}{l}\text { industrial } \\
\text { structure }^{a}\end{array}$ & $\begin{array}{l}-0.57 \\
(-0.62)^{b}\end{array}$ & 0.96 \\
\hline $\begin{array}{l}\text { United States } \\
\text { I960 }\end{array}$ & $\begin{array}{l}\text { cross section } \\
\text { all states }\end{array}$ & $\begin{array}{l}\text { industrial } \\
\text { structure }^{a}\end{array}$ & $\begin{array}{l}-8 \\
(-13)^{b}\end{array}$ & 0.77 \\
\hline $\begin{array}{l}\text { Mexico } \\
\text { I960 }\end{array}$ & $\begin{array}{l}\text { cross section } \\
5 \text { educational } \\
\text { groups }\end{array}$ & $\begin{array}{l}\text { industrial } \\
\text { structure }^{\mathrm{c}}\end{array}$ & $-\mathrm{r} .89$ to $-0.47^{\mathrm{d}}$ & 0.98 \\
\hline \multicolumn{5}{|c|}{$\begin{array}{l}\text { a American structure } 1960 .-b \text { Based on } 2 \text { nd regression. }-c \text { Japanese structure } \\
\text { I } 960 .-\mathrm{d} \text { Assuming supply elasticity to be }-\mathrm{I.25} \text { to }+ \text { o.r7. }-\mathrm{e} \text { Assuming supply } \\
\text { elasticity to be zero. }\end{array}$} \\
\hline
\end{tabular}
from Reduced-Form Price Equations 
those with third-level education increases by $\mathrm{I} \%$, hence becomes $\mathrm{I} 9 . \mathrm{I} 9 \%$ of the population, the corresponding value of $Z$ will become $0.808 \mathrm{I} \times$ $8.8+0.1919 \times 16=10.182$, whereas it was I0.I68; the increase being 0.014 . This entails a decrease of $\mathrm{X}^{\prime}$ by $-0.194 \times 0.014=-0.0027$ or by $0.12 \%\left(\mathrm{X}^{\prime}\right.$ averaging 2.28$)$. This implies a demand elasticity of $-\mathrm{I} / 0 . \mathrm{I2}=-8$. This high figure illustrates the range of uncertainty still prevailing. In another analysis, to be published elsewhere, figures around $-I$ are found for the United States.

5. The third figure mentioned in Table 4 results from an additional piece of research to be set out here. From a study by Goreux and Manne ${ }^{1}$ figures are available for income $P_{i}$ of five educational groups in Mexico, where $i$ is taken I for engineers and scientists, 2 for other professional and technical workers, 3 for administrative and clerical workers, 4 for manual and sales workers outside agriculture and 5 for unskilled agricultural workers, in I96o. Secondly figures are available for the numbers available in each of these categories, $S_{i}$. These figures are also available for $\mathrm{I}_{5}$ sectors. With their aid we calculated figures $D_{i}$ supposed to represent numbers desired by the organizers of production, by re-weighting the sector totals in the proportion they are available in Japan I96o. The idea is that the Japanese industrial structure represents a future structure for Mexico and hence expresses the direction into which demand forces "pull."

Two exercises have been made with the figures just described. Since no more than five observations are available, merely the highly simplified theory expressed in equations (I) and (2), containing only the price of the labour category under consideration, was eligible here. One only considers the reduced-form price equation, using the logarithms of the variables mentioned, indicated by the lower-case letters corresponding to the symbols just mentioned. This price equation runs:

$$
\mathrm{p}=\underset{(0.45)}{-\mathrm{r} .57 \mathrm{~s}}+\underset{(0.50)}{\mathrm{r} . \mathrm{Iod}} \quad(\mathrm{R}=0.984, \overline{\mathrm{R}}=0.979)
$$

The coefficients have the theoretically correct signs and these are significant at the $\mathrm{I} \%$ level. The influence of $\mathrm{s}$ on $\mathrm{p}$ is $-\mathrm{r} .57 \pm \mathrm{I} .05$.

It is interesting to add that if we take the I 968 values of $s$ and $d$ (for both Mexico and Japan) but the I 960 values of $p$ (since no others are available) we find

$$
\mathrm{p}=-\mathrm{I} .37 \mathrm{~s}+0.78 \mathrm{~d}
$$

${ }^{1}$ Multi-Level Planning: Case Studies in Mexico, Forew. by Hollis B. Chenery, Ed. by Louis M. Goreux and Alan S. Manne, Amsterdam, 1973. 
It is also interesting to add the result of Frisch's bunch map analysis as an alternative method of judging the reliability of the coefficients. As is well known, this method consists of comparing the results of the first, the second and the third regression equations, the latter two solved for $\mathrm{p}$ again. Thus we obtain, next to (9), the results:

$$
\begin{aligned}
& \text { 2nd regression: } \mathrm{p}=-\mathrm{I} .90 \mathrm{~s}+\mathrm{I} .38 \mathrm{~d} \\
& \text { 3rd regression: } \mathrm{p}=-2.0 \mathrm{I} \mathrm{s}+\mathrm{I} .52 \mathrm{~d}
\end{aligned}
$$

The results may be interpreted to mean that an increase in the number of academically trained manpower by I per cent reduces their incomes by I.57 to $2.0 I$ per cent and hence makes a substantial contribution to the reduction of inequality. The corresponding demand elasticities vary between -0.64 and -0.50 .

The second exercise made with the Mexican material constitutes an attempt to estimate the demand and supply equations proper: cf. equations (I) and (2). This requires more data or additional assumptions, since no direct measurements of employment $\mathrm{x}$ are available.

It seems logical to choose $\alpha_{1}=I$, if only to follow the authors who do not make a distinction between $\mathrm{x}$ and $\mathrm{s}$ at all, and taking into account the low positive supply elasticities of Table 2. In addition we may profit from Mrs. Ullman Chiswick's material for the United States in I9I0, from which she estimates $\alpha_{2}=-$ I.25. Alternatively we may follow our own tentative interpretation of her material, leaving us with $\alpha_{2}=$ o.I7. Since we found $\pi_{1}=\mathrm{I} .57$ and $\pi_{2}=\mathrm{I}$.IO, we can deduce from equation (5):

$$
\alpha_{2}+\beta_{2}=\frac{I}{I .57}=0.64 \text { and } \beta_{1}=\frac{I . I 0}{I .57}=0.70
$$

With the two alternative values of $\alpha_{2}$ just mentioned we then find either $\beta_{2}=\mathrm{I} .89$ or $\beta_{2}=0.47$, centered around unity again.

6. Summary and Conclusions. - This article lists a number of estimates, by various authors, of the substitution elasticity between highly qualified (most frequently academically trained) and other labour (Table I) and comments on the possible reasons for the diverging values shown. The most important comment is that some authors have insufficiently specified the nature of the relationship tested, i.e. not tried to identify demand and supply relationships separately. Some attempts made by the author to use material supplied by others while adding further explanatory variables in order to separate the two relationships seem to suggest that substitution elasticities close to $-\mathrm{I}$ deserve more confidence (cf. 
Table 3). Some caution is called for, however, since the values found for supply elasticities are far from uniform.

Some more light can be shed on the issue by estimates of the simple demand elasticity for academically trained labour. Results shown in Table 4 obtained by the author in different ways suggest values around -I or even lower in absolute value, although again some higher values also occur.

Zusammenfassung: Substitution von Akademikern durch andere Arbeitskräfte. - Dieser Aufsatz berichtet über Schätzungen von verschiedenen Autoren über die Substitutionselastizität zwischen hochqualifizierten (meist akademisch ausgebildeten) und anderen Arbeitskräften und befaßt sich mit den möglichen Ursachen für die Unterschiede in den ermittelten Werten. Die Hauptkritik besteht darin, daß einige Autoren die Natur der untersuchten Beziehung unzureichend spezifiziert haben, d. h. nicht versucht haben, Nachfrage- und Angebotsbeziehungen getrennt zu identifizieren. Der Verfasser versucht, Material von anderen Autoren zu verwerten und weitere erklärende Variable hinzuzufügen, um diese beiden Beziehungen zu trennen. Diese Versuche lassen vermuten, daß die Substitutionselastizitäten in der Nähe von - I liegen. Allerdings ist einige Vorsicht angebracht, da die ermittelten Werte für die Angebotselastizitäten keineswegs einheitlich sind.

Eine weitere Klärung des Problems kann mit Hilfe von Schätzungen der einfachen Nachfrageelastizität für akademisch geschulte Arbeitskräfte erreicht werden. Die Ergebnisse, die der Verfasser auf verschiedene Weise gewonnen hat, deuten darauf hin, daß die Werte bei - I oder sogar niedriger liegen dem absoluten Wert nach.

Résumé: La substitution de la main d'œuvre entraînée académiquement par d'autres groupes de la main d'œuvre. - L'article contient des estimations de l'élasticité de substitution entre la main d'œuvre bien qualifiée - dans la plupart des cas des gens formés académiquement - et d'autres groupes, données par des auteurs différents, et discute des explications possibles pour la divergence des résultats. Le point le plus important est que quelques auteurs n'ont pas spécifié suffisamment la nature des relations testées, c'est-à-dire ils n'ont pas essayé de séparer les relations de la demande et de l'offre. Quelques calculations de l'auteur qui se fondent sur le matériel des autres économistes et qui comprennent de plus d'autres variables explicatives pour la séparation des deux relations semblent indiquer que les élasticités de substitution de l'ordre - I méritent plus de confiance. Ce résultat doit être considéré avec quelque prudence parce que les valeurs trouvées pour l'élasticité de l'offre ne sont pas uniformes. Quelque progrès peut être réalisé si l'on estime l'élasticité simple de la demande à la main d'œuvre formée. Les résultats obtenus par l'auteur des manières différentes suggèrent des valeurs de l'ordre de $-\mathrm{I}$ ou même plus bas en terme absolu. 
Resumen: Sustitución de mano de obra académica por otro tipo de mano de obra. - Este artículo enumera una serie de estimaciones hechas por varios autores sobre la elasticidad de sustitución entre mano de obra altamente calificada (más frecuentemente con educación académica) por otro tipo de mano de obra y comenta las posibles razones para los valores divergentes mostrados. El comentario más importante es que algunos autores han especificado en forma insuficiente la naturaleza de las relaciones investigadas, p.ej. no haber tratado de identificar las relaciones de demanda y oferta en forma separada. Algunos intentos hechos por el autor de usar material proveido por otros, agregando algunas variables explicativas adicionales, de manera de poder separar las dos relaciones, parecen sugerir que las elasticidades de sustitución cercanas a - I son más confidentes. Estos resultados deben observarse sin embargo con cierta cautela, ya que los valores encontrados para las elasticidades de oferta son muy desiguales. Más luz se puede proyectar sobre este tema por medio de estimaciones de la elasticidad de demanda simples para la mano de obra académica. Resultados obtenidos por el autor a traves de diferentes formas indican valores alrededor de $-\mathrm{I}$ e incluso menores. 